\title{
Effects of GnRH Administered to Cows at the Onset of Estrus on Timing of Ovulation, Endocrine Responses, and Conception
}

\author{
M. Kaim*, A. Bloch†, D. Wolfenson†, R. Braw-Tal*, M. Rosenberg*, H. Voet\#, and Y. Folman* \\ *Institute of Animal Science, Agricultural Research Organization, the Volcani Center, \\ Bet Dagan 50250, Israel \\ †Department of Animal Science, and \\ \#Department of Agricultural Economics and Management, \\ Faculty of Agricultural, Food and Environmental Quality Sciences, \\ the Hebrew University of Jerusalem, \\ Rehovot 76100, Israel
}

\begin{abstract}
Two experiments examined effects of $\mathrm{GnRH}$ administered within $3 \mathrm{~h}$ after onset of estrus $(\mathrm{OE})$ on ovulation and conception in dairy cows. In experiment 1,46 cows received either saline, $250 \mu \mathrm{g}$ of $\mathrm{GnRH}$, or $10 \mu \mathrm{g}$ of the $\mathrm{GnRH}$ analogue, Buserelin. Cows were observed for estrus, blood samples were collected, and ovulations were monitored by ultrasound. In controls, $76 \%$ of cows had intervals from estrus to ovulation of $\leq 30 \mathrm{~h}$ and $24 \%$ had intervals $>30 \mathrm{~h}$. Treatment with either $\mathrm{GnRH}$ or GnRH analogue (data combined) increased magnitude of LH surges and decreased intervals from estrus to LH surge or to ovulation. Treated cows all ovulated $\leq 30 \mathrm{~h}$ after OE. Among control cows, plasma estradiol concentrations before estrus correlated positively with amplitudes of LH surges. Higher plasma progesterone was observed in the subsequent estrous cycle in $\mathrm{GnRH}-$ treated cows compared to control cows with delayed ovulations. Experiment 2 included 152 primiparous and 211 multiparous cows in summer and winter. Injection of $\mathrm{GnRH}$ analogue at $\mathrm{OE}$ increased conception rates (CR) from 41.3 to $55.5 \%$ across seasons. In summer, GnRH treatment increased CR from 35.1 to $51.6 \%$. Across seasons, GnRH increased CR from 36.0 to $61.5 \%$ in cows with lower body condition at insemination and GnRH increased CR (63.2 vs. $42.2 \%)$ in primiparous cows compared to controls. Use of $\mathrm{GnRH}$ eliminated differences in CR for cows inseminated early or late relative to $\mathrm{OE}$ and increased CR in cows having postpartum reproductive disorders. In conclusion, GnRH at onset of estrus increased LH surges, prevented delayed ovulation, and may increase subsequent progesterone concentrations. Treatments with GnRH increased conception in primiparous cows, during summer, and in cows with lower body condition.
\end{abstract}

Received August 8, 2002.

Accepted December 2, 2002.

Corresponding author: D. Wolfenson; e-mail: wolf@agri.huji.ac.il.
(Key words: GnRH, ovulation, conception, cows)

Abbreviation key: $\mathbf{O E}=$ onset of estrus, $\mathbf{C R}=$ conception rate(s).

\section{INTRODUCTION}

In most of the studies on the effect of administration of GnRH to cows during estrus on their conception rate (CR), the hormone was administered at the time of AI without consideration of the time elapsed since the onset of estrus (OE). In some of those studies, but not in others, GnRH or its analogues had a positive effect on fertility. In repeat breeders, the effect of GnRH administration was greater than at the first postpartum insemination (Mee et al., 1990; Stevenson et al., 1990). In a metaanalysis of 40 trials described in 27 papers (Morgan and Lean, 1993), a significant effect of GnRH administration at the time of AI was found: the effect on conception rates in repeat breeders was 22.5 percentage units whereas at the first postpartum AI the effect of GnRH was 5.2 percentage units and that of its analogues was 8.0 percentage units.

Improvement of conception following $\mathrm{GnRH}$ treatment during estrus has been attributed to the prevention of ovulation failure or to reduced variation in the interval to ovulation (Coulson et al., 1980; Nakao et al., 1984). However, in these studies, the effect of GnRH on the interval from $\mathrm{OE}$ to ovulation was not studied. It has also been suggested that GnRH-induced increase in progesterone concentrations during the subsequent estrous cycle may have an effect on conception; this was found in some studies (Lee et al., 1985; Mee et al., 1993; Ullah et al., 1996), but not in others (Lucy and Stevenson, 1986; Ryan et al., 1994).

In an experiment carried out in winter, it was shown that GnRH or its analogues increased CR when administered at $\mathrm{OE}$ but had no effect when administered later in the estrous period (Rosenberg et al., 1991). Also, when $\mathrm{GnRH}$ was administered at $\mathrm{OE}$, the height of the spontaneous LH peak more than doubled, whereas 
when it was administered later in the estrous period a second, smaller, LH peak emerged. In a subsequent study, GnRH administered at detection of estrus, following two daily visual observations, increased conception in dairy cows in the summer, when conception rate was very low (Ullah et al., 1996). In contrast, Mee et al. (1990) reported that GnRH administered early in estrus had no effect on the CR of dairy cows. From the conflicting results of the very few published reports on studies involving the administration of $\mathrm{GnRH}$ close to $\mathrm{OE}$, it seems that GnRH might have a considerable effect on CR under one set of conditions, but no effect under other conditions.

The objectives of the present study were to examine the effects of $\mathrm{GnRH}$, administered to high-yielding dairy cows at $\mathrm{OE}$, with $\mathrm{OE}$ being accurately determined by continuous observations for signs of estrus. Experiment 1 examined the effect of $\mathrm{GnRH}$ on preovulatory concentrations of estradiol and $\mathrm{LH}$, the interval from onset of estrus to ovulation, and subsequent plasma progesterone concentrations. Experiment 2 was a largescale experiment that examined the effects of $\mathrm{GnRH}$ on conception rates during summer and winter, in relation to BCS, parity, timing of AI, and reproductive disorders.

\section{MATERIALS AND METHODS}

\section{Animals}

The experiments were carried out in a dairy herd with 305-d average milk yields of 11,400 and 12,100 $\mathrm{kg}$ for primiparous and multiparous cows, respectively. Primiparous and multiparous cows were kept under loose housing in separate open sheds. During the summer, a combination of sprinkling and forced ventilation was practiced, as previously described (Flamenbaum et al., 1986). The cows were fed ad libitum a total mixed ration containing $1.74 \mathrm{Mcal}$ of $\mathrm{NE}_{\mathrm{L}} / \mathrm{kg}$ of $\mathrm{DM}$. They were milked three times daily, and milk yield and composition were recorded monthly. The BCS was determined, on a five-point scale (Wildman et al., 1982), by the same individual, once weekly during the $3 \mathrm{wk}$ preceding calving, immediately after calving and at 3-wk intervals thereafter. The BCS recorded closest to insemination was regarded as the BCS at AI.

The herd was under veterinary health care throughout the experiments. All cows were routinely checked and treated for health disorders twice after calving; the first check was carried out approximately 1 wk after calving and the second 6 wk after calving. Cows that were diagnosed as having a retained placenta, or metritis were regarded as having a record of reproductive disorder. Retained placenta was defined as the presence of fetal membranes $24 \mathrm{~h}$ after calving. Metritis was diagnosed according to the color, smell, amount and consistency of the vaginal discharge, and the size, position and tone of the uterus during rectal palpation and vaginal examination.

To maximize milk and calf production, primiparous cows were bred 80 to $100 \mathrm{~d}$ after calving and multiparous cows 60 to $80 \mathrm{~d}$ after calving. The management of reproduction was based on a scheme of estrous synchronization (Folman et al., 1984). At 3-wk intervals, a cluster of cows was given an estrous synchronization treatment. The experiment was conducted in accordance with the guidelines of the local ethics committee.

\section{Experiment 1}

The experiment was carried out during October and November, and involved a total of 46 cows. Estrus was synchronized by inserting a vaginal device containing $1.9 \mathrm{~g}$ progesterone (CIDR, Eazi Breed, Hamilton, New Zealand) into the vagina for $9 \mathrm{~d}$, and injecting $500 \mu \mathrm{g}$ of the $\mathrm{PGF}_{2 \alpha}$ analogue, cloprostenol (Estrumate, Coopers, Berkhamsted, UK) $2 \mathrm{~d}$ before removal of the insert. In order to avoid possible after effects of the synchronization procedure, experimental treatments were applied during the subsequent estrus ( $73 \pm 1.5 \mathrm{~d}$ after calving) and not during the synchronized estrous period that followed the insert removal.

Starting 3 wk after the synchronized estrus, continuous visual observation of estrous behavior was carried out for $24 \mathrm{~h}$ daily over $5 \mathrm{~d}$, by a team of two people. Immediately following the manifestation of the first signs of the spontaneous standing estrus, 11 cows received an i.m. injection of $250 \mu \mathrm{g}$ of $\mathrm{GnRH}(2.5 \mathrm{ml}$ of Fertagyl, Intervet, Holland), 10 cows received an i.m. injection of $10 \mu \mathrm{g}$ of the GnRH-analogue, Buserelin (2.5 $\mathrm{ml}$ of Receptal, Hoechst AG, Germany), and 25 control cows received an i.m. injection of $2.5 \mathrm{ml}$ of saline. The doses of GnRH and GnRH analogue used in this study were the doses recommended by the above-mentioned companies, for improvement of fertility. Blood samples for estradiol and LH determinations were collected every $8 \mathrm{~h}$ from 18 to $20 \mathrm{~d}$ after the synchronized estrus until the first signs of estrous behavior, and then every $3 \mathrm{~h}$ until $24 \mathrm{~h}$ after the manifestation of standing estrus. Following ovulation, blood samples for progesterone determination were collected daily during $\mathrm{d} 1$ to 8 and every other day during d 10 to 20 of the cycle. Transrectal ultrasonography of the ovaries, with a $7.5 \mathrm{MHz}$ probe (Aloka 210, Tokyo, Japan), was carried out 18 to $20 \mathrm{~d}$ after the synchronized estrus, to detect the preovulatory follicle and to confirm that the ovarian appearance was typical of the follicular phase. Commencing $20 \mathrm{~h}$ after the manifestation of standing estrus, ultrasonography of the ovaries was carried out every 4 $\mathrm{h}$ until ovulation, or until $50 \mathrm{~h}$ after $\mathrm{OE}$ in cows that 
failed to ovulate by that time. Two hours before the time when ovulation could be discerned was regarded as the time of ovulation. The size of the corpus luteum subsequent to ovulation was determined by a single ultrasonographic screening, carried out 10 to $14 \mathrm{~d}$ after estrus.

\section{Experiment 2}

The experiment was carried out during the summer (July to October) and winter seasons (November to May). During the summer, mean daily maximum and minimum air temperatures and relative humidity were 29.7 and $18.9^{\circ} \mathrm{C}$, and 71.6 and $51.7 \%$, respectively; in the winter, the respective values were 22.0 and $11.1^{\circ} \mathrm{C}$, and 76.8 and $54.4 \%$, respectively. A total of 152 primiparous and 211 multiparous cows, all healthy, were included. Before the first postpartum AI, the cows were grouped into clusters that were synchronized at 3-wk intervals with two 500- $\mu \mathrm{g}$ cloprostenol injections given $14 \mathrm{~d}$ apart. Estrous behavior of each cluster of cows was monitored for $6 \mathrm{~d}$, starting $36 \mathrm{~h}$ after the second injection of $\mathrm{PGF}_{2 \alpha}$. Constant visual observation of estrous behavior was carried out for $19 \mathrm{~h}$ daily (between 0500 and $2400 \mathrm{~h}$ ) by a team of two people. Only cows that were observed to be in estrus were included in the experiment. Cows of each cluster were randomly allotted to control or GnRH treatment groups, according to parity and BCS. Within $3 \mathrm{~h}$ following the detection of estrus, GnRH-treated cows received an i.m. injection of $10 \mu \mathrm{g}$ of the $\mathrm{GnRH}$ analogue Buserelin $(2.5 \mathrm{ml}$ of Receptal, Hoechst AG, Germany) and control cows received an i.m. injection of $2.5 \mathrm{ml}$ of saline. Cows were inseminated once daily at a fixed time by a single inseminator. Cows that did not conceive as a result of the first postpartum AI, and returned to estrus, were assigned to the opposite treatment and re-inseminated. Approximately $45 \mathrm{~d}$ after AI, pregnancy diagnosis by rectal palpation was performed by the herd veterinarian. The experiment was carried out only with respect to the first two postpartum inseminations. The conception rate was defined as the number of cows diagnosed pregnant, expressed as the percentage of total number of inseminations performed within group.

\section{Hormone Analyses}

Plasma samples were extracted for estradiol determination with diethyl ether as described by Badinga et al. (1992). Extracted plasma samples were analyzed for estradiol- $17 \beta$ concentrations by means of RIA, according to Badinga et al. (1992), and as validated in our laboratory (Shaham-Albalancy et al., 1997). The antibody, purchased from Diagnostic Products (Los
Angeles, CA) did not cross-react with testosterone or progesterone, and had low cross-reactivity with estriol $(0.2 \%)$ and estradiol $-17 \alpha(0.01 \%)$. Assay sensitivity was $0.5 \mathrm{pg} / \mathrm{ml}$, and the intra- and inter-assay coefficients of variation were 3 and 5\%, respectively. Plasma progesterone concentrations of unextracted samples were analyzed with a solid-phase RIA kit (Diagnostic Product Corp., Los Angeles, CA), against a standard curve prepared in our laboratory by dissolving progesterone in plasma from an ovariectomized cow, as described previously (Shaham-Albalancy et al., 2000). The assay sensitivity was $0.2 \mathrm{ng} / \mathrm{ml}$ and the intra- and interassay coefficients of variations were 3.9 and $8.6 \%$, respectively. Plasma LH concentrations were measured by enzyme immunoassay (EIA) with a biotin-streptavidin amplification system as described and validated for bovine plasma by Mutayoba et al. (1990). A highly purified bovine LH, USDA-bLH-B-6, was labeled with the Biotin Labeling Kit (Boehringer Mannheim, GmbH, Germany) according to the manufacturer's instructions. The assay was performed according to Mutayoba et al. (1990). A highly specific bovine LH antibody (USDA-309-684p) was used in a final dilution of 1:150,000, and a standard USDA-bLH-B-6 was used to prepare the standard curve (in hormone-stripped, charcoal-dextran-treated plasma) ranging from $0.39 \mathrm{ng} / \mathrm{ml}$ to $25 \mathrm{ng} / \mathrm{ml}$. Twenty $\mu \mathrm{l}$ of standard or unknown plasma were used in the assay. Absorbance was measured at $450 \mathrm{~nm}$ in a microtitration plate photometer. The assay was performed in duplicate; the intra- and inter-assay coefficients of variation were 8.5 and $10.6 \%$, respectively, and the assay sensitivity was $7.8 \mathrm{pg} / \mathrm{well}$. Values are expressed in $\mathrm{ng}$ of bovine $\mathrm{LH}$ per $\mathrm{ml}$.

\section{Statistical Analyses}

In experiment 1 , the elapsed times from $\mathrm{OE}$ to the peak of the LH surge and to ovulation, and the concentrations of the hormones were analyzed by means of the General Linear Model procedure of the Statistical Analysis System (SAS User's Guide, 1987, Cary, NC, USA). Differences between the two experimental groups, in those elapsed times, were analyzed by oneway ANOVA. The statistical model for hormonal concentrations (repeated measures design) included the effects of treatment (control vs. GnRH groups), cows (within treatment) which served as an error term for treatment, day of estrous cycle, and treatment-by-day interaction. In Experiment 2, multiple logistic regression was used to model the success of AI for winter and summer separately, as a function of treatment, parity, BCS, milk yield and reproductive disorders. The model also included interactions between treatment and parity, and the other variables. When interactions were 
Table 1. Time intervals (h) between the onset of estrus, peak of the preovulatory LH surge and ovulation.

\begin{tabular}{|c|c|c|}
\hline & $\begin{array}{l}\text { Control } \\
\mathrm{n}=22\end{array}$ & $\begin{array}{l}\text { GnRH } \\
\mathrm{n}=21\end{array}$ \\
\hline Interval from $\mathrm{OE}^{1}$ to peak of $\mathrm{LH}$ surge. & $3.1 \pm 0.5$ & $1.7 \pm 0.4^{*}$ \\
\hline Interval from peak of LH surge to ovulation. & $25.0 \pm 0.4$ & $23.9 \pm 0.4$ \\
\hline Interval from $\mathrm{OE}$ to ovulation of cows that ovulated within $50 \mathrm{~h}$ from $\mathrm{OE}$. & $28.2 \pm 0.6$ & $25.6 \pm 0.6^{* *}$ \\
\hline Interval from $\mathrm{OE}$ to ovulation of all cows ${ }^{2}$. & $30.8 \pm 1.5$ & $25.6 \pm 0.4^{* *}$ \\
\hline
\end{tabular}

significant at $P<0.05$ or treatment effects seemed to differ among subgroups, $\mathrm{CR}$ in the GnRH and control groups were compared by means of the chi-square test. Other specific comparisons between the GnRH and control groups were also made with the chi-square test.

\section{RESULTS}

\section{Experiment 1: Effects of GnRH Injection at Onset of Estrus on Timing of Ovulation and Endocrine Responses}

In the control group $(n=25), 19$ cows ovulated within $30 \mathrm{~h}$ of $\mathrm{OE}$, three cows ovulated later than $30 \mathrm{~h}$, and three cows did not ovulate within the $50 \mathrm{~h}$ of ultrasonographic observation. The ultrasonographic screening that was performed 10 to $14 \mathrm{~d}$ after estrus revealed that the three control cows that did not ovulate within $50 \mathrm{~h}$, had a corpus luteum indicative of eventual ovulation. Therefore, for those last three cows, a minimum value of 50-h was designated to the interval from $\mathrm{OE}$ to ovulation. Of the six cows ( $24 \%$ of control cows) that ovulated later than $30 \mathrm{~h}$ after $\mathrm{OE}$, one was primiparous and the other five were multiparous animals. In the GnRH group $(\mathrm{n}=21)$, all cows ovulated within $30 \mathrm{~h}$ of $\mathrm{OE}$. As there were only small and nonsignificant differences, between cows that were treated with Fertagyl and cows that were treated with Buserelin, the data of the two subgroups were combined and are presented as those of the GnRH group. The GnRH treatment decreased the time interval from $\mathrm{OE}$ to the $\mathrm{LH}$ surge peak $(3.1 \pm 0.5$ vs. $1.7 \pm 0.4 \mathrm{~h} ; P<0.05)$, but did not affect the interval from the peak of LH surge to ovulation (Table 1). Thus, the significant difference between the control and the GnRH groups (that ovulated within 50 $\mathrm{h}$ of $\mathrm{OE}$ ), in the interval from $\mathrm{OE}$ to ovulation, was the result of the differing intervals from $\mathrm{OE}$ to the peak of the LH surge (Table 1).

The peak of the preovulatory LH surge of control cows (excluding the three cows that ovulated later than 50 h after $\mathrm{OE}$ ) was $9.7 \pm 1.1 \mathrm{ng} / \mathrm{ml}$, compared with $15.5 \pm$ $1.1 \mathrm{ng} / \mathrm{ml}$ in the GnRH group $(P<0.01$; Figure 1$)$. The area under the curve of the LH surge was calculated as the integral of the $\mathrm{LH}$ concentrations over a period extending from $6 \mathrm{~h}$ before to $6 \mathrm{~h}$ after the peak of the LH surge. Analysis indicated that the area under the curve was increased by the GnRH treatment: $46.1 \pm 3.6$ and $61.2 \pm 3.7 \mathrm{ng} / \mathrm{ml}$ in the control and treatment groups, respectively $(P<0.05)$.

Plasma estradiol concentrations at $\mathrm{OE}$ did not differ between the treatments (Figure 2). In the control group, the coefficients of correlation between plasma estradiol concentrations $8 \mathrm{~h}$ before $\mathrm{OE}$ and at $\mathrm{OE}$, and the height of the LH peak were $0.40(P<0.05)$ and $0.56(P<0.01)$, respectively. In the GnRH-treated group, the coefficients of correlation between the same variables were small and not statistically significant. Plasma progesterone concentrations before estrus did not differ among

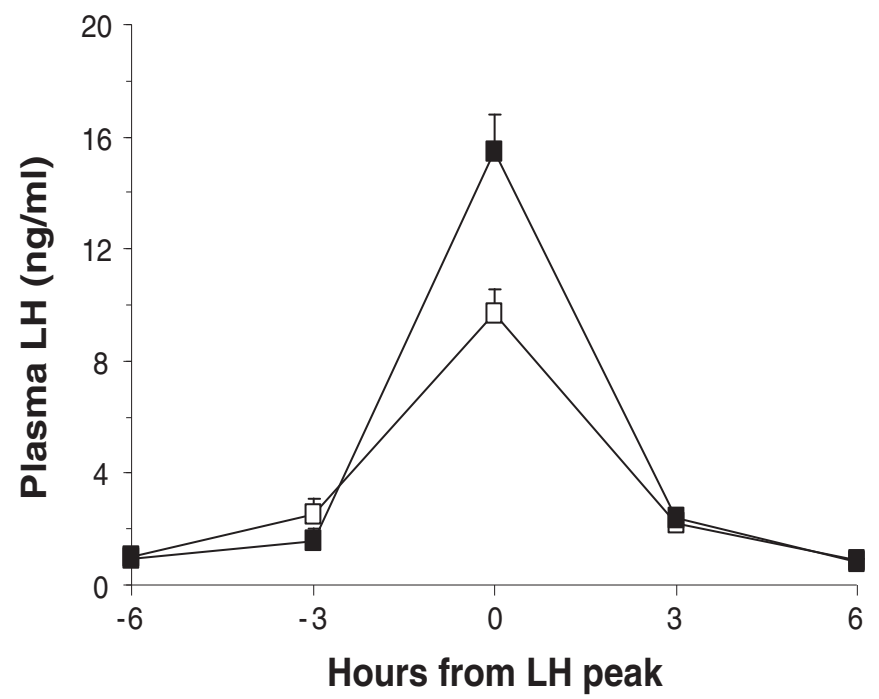

Figure 1. Peripheral plasma LH concentrations before and after the preovulatory LH surge of control cows $(\square)$ and GnRH-treated cows (ם). The height of the surge and the area under the curve of control cows are less than those of treated cows $(P<0.05)$. 


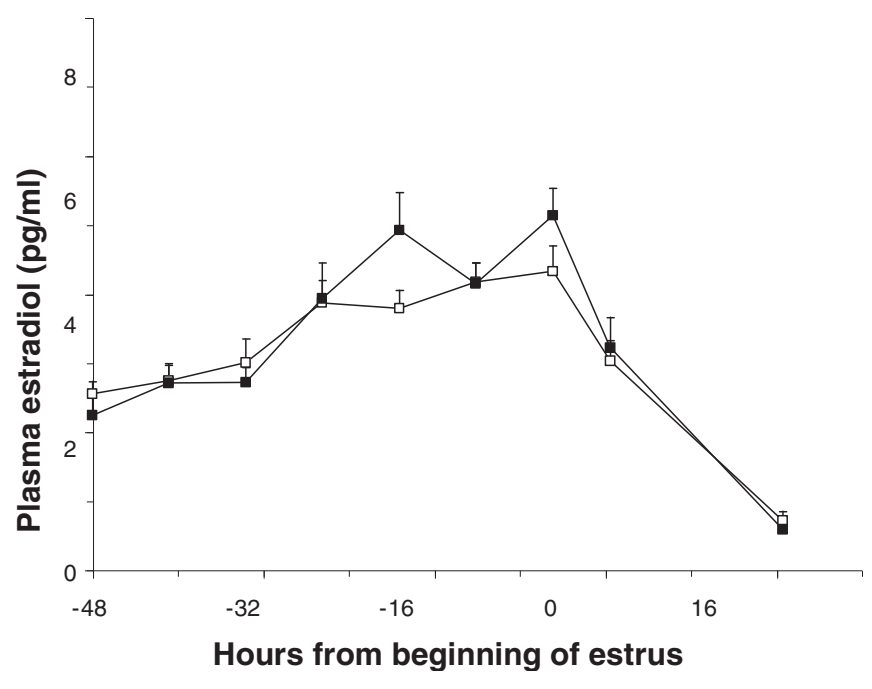

Figure 2. Peripheral plasma concentrations of estradiol before and after the onset of standing estrus in control ( $\square$ ) and GnRHtreated cows (ם).

the experimental groups (data not shown). There was also no significant difference in progesterone concentrations between the $\mathrm{GnRH}$ and control groups during the subsequent estrous cycle (Figure 3). Similarly, the mean diameter of the corpus luteum, as determined between 10 and $14 \mathrm{~d}$ after estrus, did not differ between the control and the GnRH-treated groups $(25.4 \pm 0.6$ and $25.9 \pm 0.6 \mathrm{~mm}$, respectively). On $\mathrm{d} 11$ to 16 of the estrous cycle, the mean progesterone concentration of the GnRH group was $6.5 \pm 0.41$, compared with $5.6 \pm$ $0.33 \mathrm{ng} / \mathrm{ml}$ in the control group; this difference only tended to be significant $(P<0.12)$. However the proges-

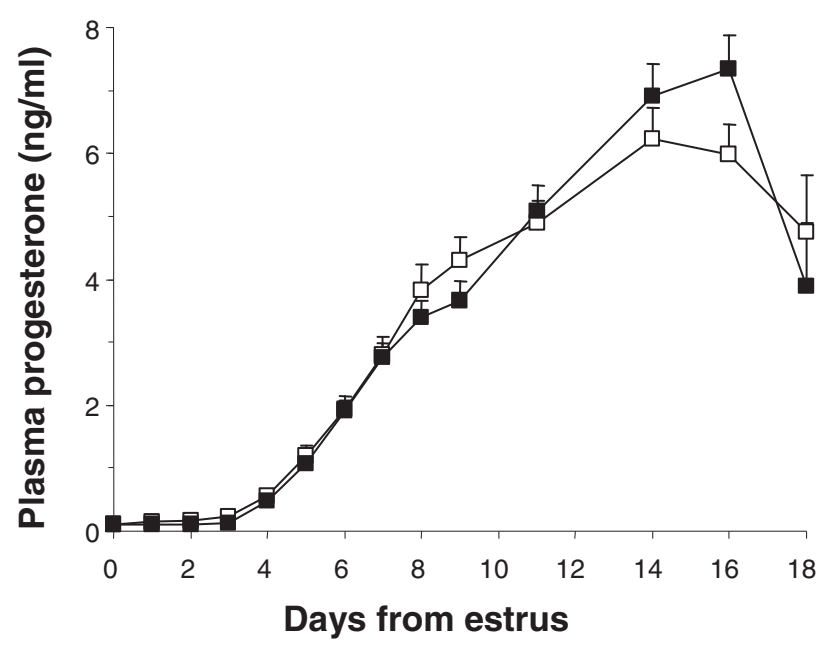

Figure 3. Peripheral plasma progesterone concentration during the estrous cycle following the GnRH administration in control ( $\square$ ) and GnRH-treated cows (ם). terone concentration of the GnRH group was higher than that of the six control cows that did not ovulate within $30 \mathrm{~h}$ of $\mathrm{OE}(6.5 \pm 0.4 \mathrm{vs} .4 .5 \pm 0.2 \mathrm{ng} / \mathrm{ml} ; P<0.01)$.

\section{Experiment 2: Effects of GnRH Injection at Onset of Estrus on Conception Rate, in Relation to Season, Parity, Body Condition and Reproductive Disorders}

Logistic regressions to model $\mathrm{CR}$ as a function of treatment, $\mathrm{BCS}$ at $\mathrm{AI}$ and parity, together with interactions of treatment by BCS and treatment by parity, showed that in summer BCS had a significantly positive effect on $\mathrm{CR}(P<0.03)$, and the tendency to significance of treatment by parity interaction $(P<0.08)$ suggested a stronger effect of treatment on primiparous cows. The same model for the winter data showed a positive effect for treatment $(P<0.05)$ and borderline significance $(P$ $<0.06$ ) for treatment by BCS interaction, showing a weaker treatment effect for cows with high BCS. For data of both seasons together, the season effect was added to the above model. The treatment, BCS and winter main effects were significantly positive $(P<0.02$, $P<0.01$ and $P<0.002$, respectively), and the treatment by BCS and treatment by parity interactions were also significant $(P<0.03$ and $P<0.05$, respectively). Further chi-square tests showed the following specific results. Administration of $\mathrm{GnRH}$ at $\mathrm{OE}$ increased the overall CR by 14.2 percentage units $(P<0.01)$. This increase was due mainly to the significant effect of $\mathrm{GnRH}$ in summer, when it increased the CR from 35.1 to $51.6 \%$ $(P<0.01 ;$ Table 2). The effect of GnRH treatment on primiparous cows was statistically significant $(P<$ 0.01 ), whereas the effect on multiparous cows was not significant (Table 2). The increase was again mainly due to a significant effect of treatment during the summer, when GnRH almost doubled the CR of primiparous cows (from 33.3 to $60.3 \% ; P<0.01$ ). It is noteworthy that GnRH-treated cows had a similar CR in summer to that of control cows in winter.

Cows were divided into low- and high-BCS subgroups. For each experimental group, within parity and season, the value of the median BCS at AI was calculated. Cows with BCS lower or higher than the respective median values were designated to low- or highBCS groups. Mean values of BCS of the low- and highBCS subgroups were, respectively, $3.0 \pm 0.02$ and 3.3 $\pm 0.03(P<0.01)$ at calving, and $2.2 \pm 0.02$ and $2.8 \pm$ $0.02(P<0.01)$ at AI, and the decreases in BCS between calving and AI were $0.80 \pm 0.02$ and $0.55 \pm 0.02(P<$ 0.01 ), respectively. In both seasons, GnRH increased the CR of cows with a low BCS at AI from 36.0 to $61.5 \%$ $(P<0.01)$, but did not affect the CR of cows with a 
Table 2. The effect of $\mathrm{GnRH}$ administered to cows at onset of estrus on conception rates ${ }^{1}(\%)$ in relation to $\mathrm{BCS}$ at $\mathrm{AI}^{2}$ and parity following the first and second postpartum $\mathrm{AI}$, during summer and winter.

\begin{tabular}{|c|c|c|c|c|c|c|}
\hline & \multicolumn{2}{|c|}{ Summer } & \multicolumn{2}{|c|}{ Winter } & \multicolumn{2}{|c|}{ Summer and Winter } \\
\hline & Control & GnRH & Control & GnRH & Control & $\mathrm{GnRH}$ \\
\hline \multicolumn{7}{|l|}{$\mathrm{BCS}$ at $\mathrm{AI}$} \\
\hline Low & $30.7(75)^{3}$ & $53.8^{* *}(78)$ & $47.2(36)$ & $76.9^{\mathrm{a} * *}(39)$ & 36.0 & $61.5^{* *}(117)$ \\
\hline High & $39.0(82)$ & $49.4(79)$ & $61.5(39)$ & $50.0^{\mathrm{b}}(42)$ & 46.3 (121) & 49.6 (121) \\
\hline \multicolumn{7}{|l|}{ Parity } \\
\hline Primiparous & $33.3(57)$ & $60.3^{* *}(63)$ & $57.6(33)$ & $68.8(32)$ & $42.2(90)$ & $63.2^{\mathrm{a} * *}(95)$ \\
\hline Multiparous & $36.0(100)$ & $45.7(94)$ & $52.4(42)$ & $59.2(49)$ & 40.8 & $50.3^{\mathrm{b}}(143)$ \\
\hline Overall & 35.1 (157) & $51.6 * *(157)$ & $54.7(75)$ & $63.0(81)$ & $41.3(232)$ & $55.5^{* *}(238)$ \\
\hline
\end{tabular}

\footnotetext{
${ }^{1}$ Conception rate $=$ Number of cows diagnosed pregnant, expressed as the percentage of total number of inseminations performed within group.

${ }^{2} \mathrm{BCS}=$ body condition score. Cows of each experimental group, within parity and season, were divided into low and high BCS by their respective medians. Mean values of low- and high-BSC groups at AI are: 2.2 and 2.8 , respectively.

${ }^{3}$ No. of $\mathrm{AI}$ in parentheses.

$* * P<0.01$, significantly different from the control group.

${ }^{\mathrm{a}, \mathrm{b}}$ Conception rates within the same column with no common superscript letters differ significantly $(P<$ 0.05).
}

high BCS at AI (Table 2). Interestingly, among GnRHtreated animals in the winter, cows with a low BCS at $\mathrm{AI}$ had a higher $\mathrm{CR}$ than cows with a high BCS at AI (76.9 vs. $50.0 \% ; P<0.05$ ).

The timing of AI within the estrous period affected the CR of control cows in summer but not in winter (Table 3): the CR of cows inseminated between 4 and $20 \mathrm{~h}$ after the detection of estrus was almost twice as high as those of cows receiving AI before $3 \mathrm{~h}$ or after $20 \mathrm{~h}(P<0.06)$. In summer, the greatest increases in $\mathrm{CR}$, in GnRH-treated compared with control cows, were associated with the early $\mathrm{AI}$ ( +20 percentage units; NS) and late $\mathrm{AI}(+47 \% ; P<0.01)$. No such tendency could be detected during the summer in the GnRH-treated group, in which a nonsignificant increase in CR with increasing time between $\mathrm{OE}$ and $\mathrm{AI}$ was noted. It should be noted that the data on early and late AI should be treated with caution, because of the small numbers of such inseminations.
The effect of GnRH on CR was not affected by milk yield. When the data from cows of both treatments were combined, cows with a high milk yield $(46.2 \pm 0.7 \mathrm{FCM}$, $\mathrm{kg} / \mathrm{d}$; average of the higher median) during the second and third months after calving, had a higher CR (53.7 vs. $43.5 \% ; P<0.05$ ) than those with a lower milk yield (38.8 $\pm 0.6 \mathrm{FCM}, \mathrm{kg} / \mathrm{d}$; average of the lower median).

In summer, control cows with a low BCS at AI, and those that had postpartum reproductive disorders, had a lower CR than healthy cows ( 11.8 vs. $38.7 \%, P<0.05$; Table 4), whereas similar cows that received GnRH treatment had a similar CR to that of healthy cows. Overall, GnRH treatment more than doubled the CR of cows with reproductive disorders $(P<0.01)$, whereas its effect in healthy cows was nonsignificant.

\section{DISCUSSION}

It was previously suggested that administering $\mathrm{GnRH}$ at estrus might prevent ovulation failure or re-

Table 3. The effect of GnRH on conception rates $^{1}(\%)$ of cows in relation to timing of AI during the estrous period in summer and winter.

\begin{tabular}{|c|c|c|c|c|}
\hline \multirow{2}{*}{$\begin{array}{l}\text { Time interval } \\
\text { from } \mathrm{OE}^{3} \text { to } \mathrm{AI}, \mathrm{h}\end{array}$} & \multicolumn{2}{|c|}{ Summer } & \multicolumn{2}{|c|}{ Winter } \\
\hline & Control & $\mathrm{GnRH}$ & Control & GnRH \\
\hline $0-3$ & $22.7(22)^{2}$ & $42.9(21)$ & $55.6(9)$ & $55.6(9)$ \\
\hline $4-20$ & $38.7(124)$ & $51.3^{*}(119)$ & $51.9(54)$ & $62.5(64)$ \\
\hline $21-24$ & $18.2^{4}(11)$ & $64.7^{*}(17)$ & $66.7(12)$ & $75.0(8)$ \\
\hline \multicolumn{5}{|c|}{$\begin{array}{l}{ }^{1} \text { Conception rate }=\text { Number of cows diagnosed pregnant, expressed as the percentage of total number of } \\
\text { nseminations performed within group. }\end{array}$} \\
\hline \multicolumn{5}{|c|}{${ }^{2} \mathrm{No}$. of $\mathrm{AI}$ in parentheses. } \\
\hline \multicolumn{5}{|c|}{${ }^{3} \mathrm{OE}=$ onset of estrus. } \\
\hline \multicolumn{5}{|c|}{$\begin{array}{l}{ }^{4} 0 \text { to } 3 \mathrm{~h} \text { and } 21 \text { to } 24 \mathrm{~h} \mathrm{AI} \text { in summer control cows gave lower conception rates than in control cows } \mathrm{AI} \\
4 \text { to } 20 \mathrm{~h} \text { after } \mathrm{OE}(P<0.06) \text {. }\end{array}$} \\
\hline
\end{tabular}


Table 4. The effect of GnRH on conception $\operatorname{rates}^{1}(\%)$ in the summer in cows with postpartum reproductive disorders.

\begin{tabular}{|c|c|c|c|c|}
\hline \multirow[b]{2}{*}{$\mathrm{BCS}$ at $\mathrm{AI}^{2}$} & \multicolumn{2}{|c|}{ Healthy cows } & \multicolumn{2}{|c|}{ Cows with disorders } \\
\hline & Control & GnRH & Control & GnRH \\
\hline Low & $38.7(75)^{3}$ & $50.8(65)$ & $11.8^{*}(17)$ & $51.9^{* *}(27)$ \\
\hline High & 38.8 (49) & 50.0 & $31.3(16)$ & 57.9 (19) \\
\hline Overall & $38.7(124)$ & $50.0(111)$ & $21.2(33)$ & $54.4^{* *}(46)$ \\
\hline
\end{tabular}

\footnotetext{
${ }^{1}$ Conception rate $=$ Number of cows diagnosed pregnant, expressed as the percentage of total number of inseminations performed within group.

${ }^{2} \mathrm{BCS}=$ body condition score. Cows of each group and parity were divided into low and high BCS by their respective medians.

${ }^{3}$ No. of $\mathrm{AI}$ in parentheses.

$* P<0.05$, significant from the respective healthy control group.

$* * P<0.01$, significant from respective control cows with disorders.
}

duce the variation in the time interval to ovulation (Coulson et al., 1980; Nakao et al., 1984). In the present study, all GnRH-treated cows ovulated within $30 \mathrm{~h}$ after $\mathrm{OE}$, whereas $24 \%$ of the control cows ovulated later. This delay in ovulation relative to the timing of estrus and AI might reduce fertilization (Saacke et al., 2000) and pregnancy rates. An extreme delay in ovulation, such as those recorded in the three control cows that ovulated later than $50 \mathrm{~h}$ after $\mathrm{OE}$, in the present study, could affect fertilization and also delay the establishment of luteal function (Larson et al., 1997) and consequently reduce fertility. Thus, if $\mathrm{GnRH}$ treatment were given at $\mathrm{OE}$, failure or delay of ovulation might be prevented and CR might increase. On the other hand, if $\mathrm{GnRH}$ is administered at the time of AI, especially when detection of estrus is not carried out frequently, the administration is likely, in most cases, to be rather late in estrus, with unknown effects on the timing of ovulation, and a prospective decline in plasma progesterone levels in the subsequent luteal phase (Ryan et al., 1994).

It has been shown previously, in first postpartum $\mathrm{AI}$ cows, that when GnRH is administered at OE, the GnRH-induced LH peak coincides with the spontaneous LH peak, and the resulting merged peak is higher than either the spontaneous LH peak in the control group or the peak induced late in estrus by GnRH (Rosenberg et al., 1991). In the present study similar results were obtained: GnRH at $\mathrm{OE}$ increased both the LH peak height and the area under the curve, whereas, in contrast, in most other studies GnRH administered at AI induced a second LH peak and did not increase the spontaneous one (Lee et al., 1985; Lucy and Stevenson, 1986; Ryan et al., 1994). These findings could be related to the fact that repeat breeder heifers have a smaller preovulatory LH surge than virgin heifers (Gustafsson et al., 1986) and, therefore, an increase in the spontaneous surge that results from the administration of $\mathrm{GnRH}$ at $\mathrm{OE}$ affects the CR favorably.
The fact that six control cows ovulated more than 30 $\mathrm{h}$ after $\mathrm{OE}-$ three of them more than $50 \mathrm{~h}$ after $\mathrm{OE}-$ could be related to the low preovulatory LH surge in the control group. Recently, we characterized a subgroup of high-yielding Holstein cows with very long intervals between estrus and ovulation, and between LH surge and ovulation; they were associated with a markedly low preovulatory LH surge and lower than usual concentrations of estradiol in the follicular phase before estrus (Bloch et al., 2001). These findings are in agreement with those of the present study, in which we found in the control group a significant correlation between estradiol concentrations at and before estrus, and the height of the LH peak. Collectively, these results suggest that the phenomenon of an unusually extended interval between estrus and ovulation may result from impairment of the preovulatory follicle function. The results indicate that the GnRH treatment may have enabled cows with low estradiol concentrations before estrus to achieve a larger LH peak, which, in turn, enabled all the cows to ovulate within $30 \mathrm{~h}$ of $\mathrm{OE}$. This interpretation is also supported by the lack of significant correlation, in the treatment group, between estradiol levels during proestrus and the height of the peak LH surge. It should be mentioned, however, that, to the best of our knowledge, there is no direct evidence for a relationship between a low LH surge and a long interval to estrus.

In various studies, progesterone concentration has either increased, decreased or remained unchanged during the luteal phase, following GnRH administration (Lee et al., 1985; Lucy and Stevenson, 1986; Mee et al., 1993; Ryan et al., 1994; Ullah et al., 1996). In these experiments GnRH or its analogues were administered in different seasons, at first postpartum $\mathrm{AI}$ or to repeat breeders, either at $\mathrm{OE}$ or later in estrus, following estrous behavior or at a fixed time after $\mathrm{PGF}_{2 \alpha}$ treatment. The many variations in the conditions under which GnRH was administered may have led to dif- 
fering effects on the formation of the corpus luteum and, hence, on the plasma progesterone levels during the subsequent luteal phase. In the present study, no significant difference in plasma progesterone concentrations between overall control and $\mathrm{GnRH}$ groups could be discerned. However, control cows with a long OE-to-ovulation interval had lower progesterone concentrations than GnRH-treated cows, during days 11 to 16 of the subsequent estrous cycle. Furthermore, we have previously shown that untreated cows with a very long interval between estrus and ovulation had significantly lower plasma progesterone concentrations in the mid-luteal phase of the subsequent estrous cycle than cows with a normal interval (Bloch et al., 2001). These results indicate that at least some cows have a low preovulatory LH surge, ovulate late after estrus, and may be deficient in progesterone in the subsequent luteal phase. In light of reports that repeat breeder cows and heifers had lower plasma progesterone levels than control animals in the estrous cycle subsequent to AI (Gustafsson et al., 1986; Kimura et al., 1987; Maurer and Echternkamp, 1985), the GnRH-induced increase in blood progesterone levels in repeat breeder cows (Mee et al., 1993) might be one of the causes of the increased conception rates in these cows, as well as of those found in other experiments in which cows exhibited low progesterone concentrations (Ullah et al., 1996).

Administering $\mathrm{GnRH}$ or its analogues to cows at the time of AI increased CR in some experiments, but not in others (Mee et al., 1990; Stevenson et al., 1990). With late AI, cows treated early in estrus had a higher CR than those treated late in estrus (Rosenberg et al., 1991). The latter study, conducted in the winter, and that by Ullah et al. (1996) under heat-stress conditions, both indicated that GnRH treatment at $\mathrm{OE}$ significantly improved CR, particularly when the CR of untreated cows was low. In keeping with these results, the present study found that CR was improved by GnRH in summer, when the CR of control cows was low, and not in the winter when it was markedly higher. It is interesting that within the control group, in summer but not in winter, early and late AI resulted in lower $\mathrm{CR}$ than $\mathrm{AI}$ administered between 4 and $20 \mathrm{~h}$ after OE. These findings are similar to those reported by Nebel et al. (2000) based on a large data set collected from 17 herds and 2661 inseminations, in which $\mathrm{OE}$ was detected by the radiotelemetric HeatWatch system. In contrast, the CR in GnRH-treated cows increased gradually with increasing time between $\mathrm{OE}$ and $\mathrm{AI}$, and the difference in $\mathrm{CR}$ between those receiving $\mathrm{AI}$ early and those inseminated late reached a maximum of $47 \%$. These findings are in agreement with those of Saacke et al. (2000) and Dalton et al. (2001), who reported that early AI reduced the fertilization rate, and that late AI reduced the embryo quality.

The findings of the present study indicate that GnRH treatment increased the CR mainly in cows with a low BCS at AI. The greater postpartum body condition deterioration in cows with a low $\mathrm{BCS}$ at $\mathrm{AI}$, observed in the present study, suggests that these cows had a greater negative energy balance after calving than those with a high BCS at AI (Butler and Smith, 1989; Ferguson and Otto, 1989). It seems reasonable to assume that the main reason for the positive effect of $\mathrm{GnRH}$ on the CR of low BCS cows is that these cows also had lower CR than the high-BCS ones within each season, so that there was a greater potential for fertility improvement. A greater effect of $\mathrm{GnRH}$, administered at $\mathrm{OE}$, on cows exhibiting low fertility was also reported by Rosenberg et al. (1991). Recently, Butler (2000) suggested that the low fertility of the dairy cow under negative energy balance is associated with low estrogen and LH secretion, which could be due to low glucose, insulin and IGFI secretion, and that part of the low-fertility syndrome could be related to low secretion of progesterone as well. Interestingly, in contrast to the present study, in timed AI protocols (Ovsynch), in which GnRH was injected at a fixed time after $\mathrm{PGF}_{2 \alpha}$ injection and cows were inseminated at a further fixed time later (and not at $\mathrm{OE}$, as in the present study), CR was higher in cows with high BCS than in cows with low BCS (Moreira et al., 2000). The higher response to $\mathrm{GnRH}$ in cows with high BCS, found in the latter study, was attributed to an earlier postpartum resumption of cyclicity.

The reason for the greater beneficial effect of $\mathrm{GnRH}$ on primiparous cows than on multiparous cows is unclear. Primiparous cows usually have a higher CR than multiparous cows; a 7- to 8-percentage unit higher conception rate for primiparous cows was recorded in 2000 in the Israeli Holstein Herd book. It may be speculated that $\mathrm{GnRH}$ treatment removes various limiting factors that decrease CR, and thus allows better realization of the fertility potential, which may be higher in primiparous cows. Similarly, the reason for the greater beneficial effect of GnRH on cows with postpartum reproductive disorders is also unclear. It has been shown that postpartum reproductive disorders are associated with increased risk for abnormal cyclicity (Opsomer et al., 2000). It may be speculated that abnormal cyclicity is associated with low preovulatory LH secretion, delayed ovulation and low progesterone secretion after estrus. It is hypothesized that GnRH at OE improved endocrine responses that had been impaired by the previous uterine disorders.

GnRH treatment almost annulled the negative effect of summer heat stress on fertility; however, the effect was pronounced and significant in primiparous cows 
but not in multiparous cows. A possible explanation for the greater effect of $\mathrm{GnRH}$ in summer could be related to an attenuated preovulatory LH surge and its possible association with low postovulation progesterone concentrations. Lactating dairy cows under chronic summer heat stress or under acute heat exposure exhibited a reduced preovulatory LH surge (Gilad et al., 1993). Recently, possible relationships between low LH surge and low in vitro secretion of progesterone by luteinized granulosa cells, and between a low GnRH-induced LH surge and low plasma progesterone concentrations at mid-luteal phase were reported (Less et al., 1998; Biger et al., 2000). A similar relationship between low LH surge and low postovulation progesterone concentration was found in primates (Zelinski-Wooten et al., 1997). In agreement with these findings, hCG administered to cows on day 5 of the cycle induced a greater increase in progesterone concentrations than the $\mathrm{GnRH}$ analogue Buserelin, that is known to induce a narrow LH surge (Schmitt et al., 1996), and the potent GnRH implant Deslorelin induced a higher surge of $\mathrm{LH}$ and higher postovulation progesterone concentrations than Buserelin (Ambrose et al., 1998; Rajamahendran et al., 1998). Collectively, the above observations could be associated with the findings that plasma progesterone concentrations are lower in cows under chronic summer heat stress than in their counterparts under winter conditions (Wolfenson et al., 2002). Under the former conditions, GnRH treatment at OE has a greater potential to improve hormonal secretion and hence the fertility of lactating cows in the summer.

\section{CONCLUSIONS}

Use of $\mathrm{GnRH}$ at the onset of estrus increases the spontaneous LH peak, prevents delays in ovulation, and induces uniformly high postovulation progesterone concentrations. Under these conditions, GnRH has the potential to increase conception rates considerably in high-yielding dairy cows under low-fertility conditions. Treatment with GnRH may yield better fertility results in cows with a low BCS at AI, and in primiparous cows than in multiparous ones. The effect of $\mathrm{GnRH}$ on increasing conception rate is greater in summer, under heat-stress conditions, than in winter.

\section{ACKNOWLEDGMENTS}

The authors thank Y. Graber for her technical assistance, USDA for provision of bovine LH antibody, and the dairy team of Kibbutz Naan, Israel, for their skillful assistance.

\section{REFERENCES}

Ambrose, J. D., M. F. Pires, F. Moreira, T. Diaz, M. Binelli, and W. W. Thatcher. 1998. Influence of deslorelin (GnRH-agonist) implant on plasma progesterone, first wave dominant follicle and pregnancy in dairy cattle. Theriogenology 50:1157-1170.

Badinga, L., M. A. Driancourt, J. D. Savio, D. Wolfenson, M. Drost, R. L. De La Sota, and W. W. Thatcher. 1992. Endocrine and ovarian response associated with the first wave dominant follicle in cattle. Biol. Reprod. 47:871-883.

Biger, E., D. Wolfenson, R. Mamluk, N. Levi, Y. Graber, and R. Meidan. 2000. Effects of LH 'surge' patterns on the steroidogenic capacity of bovine follicular cells luteinized in vitro. 14th Int. Cong. Anim. Reprod. Stockholm 1:27(Abstr.).

Bloch, A., D. Wolfenson, M. Kaim, Z. Roth, R. Braw-Tal, and Y. Folman. 2001. Factors affecting the time intervals between estrus, LH surge and ovulation in high-yield dairy cows. J. Dairy Sci. 84(Suppl. 1):464(Abstr.).

Butler, W. R. 2000. Nutritional interactions with reproductive performance in dairy cattle. Anim. Reprod. Sci. 60-61:449-457.

Butler, W. R., and R. D. Smith. 1989. Interrelationships between energy balance and postpartum reproductive function in dairy cattle. J. Dairy Sci. 72:767-783.

Coulson, A., D. E. Noakes, J. Hamer, and T. Cockril. 1980. Effect of gonadotrophin releasing hormone on levels of luteinising hormone in cattle synchronised with dinoprost. Vet. Rec. 107:108109.

Dalton, J. C., S. Nadir, J. H. Bame, M. Noftsinger, R. L. Nebel, and R. G. Saacke. 2001. Effect of time of insemination on number of accessory sperms, fertilization rate, and embryo quality in nonlactating dairy cattle. J. Dairy Sci. 84:2413-2418.

Ferguson, J. D., and K. A. Otto. 1989. Managing body condition in dairy cows. Page 75 in Proc. Cornell Nutr. Conf. for Feed Manuf., Syracuse, NY. Cornell Univ., Ithaca, NY.

Flamenbaum, I., D. Wolfenson, and A. Berman. 1986. Cooling dairy cattle by a combination of sprinkling and forced ventilation and its implementation in the shelter system. J. Dairy Sci. 69:3140-3147.

Folman, Y., M. Kaim, Z. Herz, and M. Rosenberg. 1984. Reproductive management of dairy cattle based on the synchronization of estrous cycles. J. Dairy Sci. 67:153-160.

Gilad, E., R. Meidan, A. Berman, Y. Graber, and D. Wolfenson. 1993. Effect of heat stress on tonic and $\mathrm{GnRH}$ induced gonadotrophin secretion in relation to concentration of oestradiol in plasma of cycling cows. J. Reprod. Fertil. 99:315-321.

Gustafsson, H., K. Larsson, H. Kindahl, and A. Madej. 1986. Sequential endocrine changes and behaviour during oestrus and metoestrus in repeat breeders and virgin heifers. Anim. Reprod. Sci. 10:261-273.

Kimura, M., T. Nakao, M. Moriyoshi, and K. Kawata. 1987. Luteal phase deficiency as a possible cause for repeat breeding in dairy cows. Br. Vet. J. 143:560-566.

Larson, S. F., W. R. Butler, and W. B. Currie. 1997. Reduced fertility associated with low progesterone postbreeding and increased milk urea nitrogen in lactating cows. J. Dairy Sci. 80:1288-1295.

Lee, C. N., J. K. Kritser, and R. L. Ax. 1985. Changes of luteinizing hormone and progesterone for dairy cows after gonadotrophinreleasing hormone at first postpartum breeding. J. Dairy Sci. 68:1463-1470.

Less, M., D. Wolfenson, A. Shaham-Albalancy, Z. Roth, and R. Meidan. 1998. Effects of LH surge patterns on progesterone secretion during development of the corpus luteum and in vitro luteinization of granulosa and theca cells in cows. Page 76 in Ann. Meeting for the Study of Fertility. Glasgow (Abstr.).

Lucy, M. C., and J. S. Stevenson. 1986. Gonadotrophin-releasing hormone at estrus: Luteinizing hormone, estradiol and progesterone during the periestrual and postinsemination periods in dairy cattle. Biol. Reprod. 35:300-311.

Maurer, R. R., and S. E. Echternkamp. 1985. Repeat-breeder females in beef cattle: Influences and causes. J. Anim. Sci. 61:624-636.

Mee, M. O., J. S. Stevenson, R. K. Scoby, and Y. Folman. 1990. Influence of gonadotrophin-releasing hormone and timing of in- 
semination relative to estrus on pregnancy rates of dairy cattle at first service. J. Dairy Sci. 73:1500-1507.

Mee, M. O., J. S. Stevenson, B. M. Alexander, and R. G. Sasser. 1993. Administration of $\mathrm{GnRH}$ at estrus influences pregnancy rates, serum concentration of LH, FSH, estradiol-17 $\beta$, pregnancy specific protein $\mathrm{B}$, and progesterone, proportion of luteal cell types, and in vitro production of progesterone in dairy cows. J. Anim. Sci. 71:185-198.

Moreira, F., C. Risco, M. F. A. Pires, J. D. Ambrose, M. Drost, M. DeLorenzo, and W. W. Thatcher. 2000. Effect of body condition on reproductive efficiency of lactating dairy cows receiving a timed insemination. Theriogenology 53:1305-1319.

Morgan, W. F., and I. L. Lean. 1993. Gonadotrophin-releasing hormone treatment in cattle: A meta-analysis of the effects on conception at the time of insemination. Aust. Vet. J. 70:205-209.

Mutayoba, B. M., H. H. D. Meyer, D. Schams, and E. Schallenberger. 1990. Development of a sensitive enzyme immunoassay for LH determination in bovine plasma using the streptoavidin-biotin technique. Acta Endocrinol. 122:227-232.

Nakao, T., J. Shirakawa, M. Tsurubayashi, K. Oboshi, T. Abe, Y. Sawamukai, N. Saga, N. Tsunoda, and K. Kawata. 1984. A preliminary report on the treatment of ovulation failure in cows with gonadotrophin-releasing hormone analog or human chorionic gonadotrophin combined with insemination. Anim. Reprod. Sci. 7:489-495.

Nebel, R. L., M. G. Dransfield, S. M. Jobst, and J. H. Bame. 2000. Automated electronic systems for the detection of oestrus and timing of AI in cattle. Anim. Reprod. Sci. 60-61:713-723.

Opsomer, G., Y. T. Grohn, J. Hertl, M. Coryn, H. Deluyker, and A. de Kruif. 2000. Risk factors for post partum ovarian dysfunction in high producing dairy cows in Belgium: A field study. Theriogenology 53:841-857.

Rajamahendran, R., J. D. Ambrose, E. J. Schmitt, M. J. Thatcher, and W. W. Thatcher. 1998. Effects of buserelin injection and deslorelin (GnRH-agonist) implants on plasma progesterone, $\mathrm{LH}$, accessory CL formation, follicle and corpus luteum dynamics in Holstein cows. Theriogenology 50:1141-1455.

Rosenberg, M., S. Y. Chun, M. Kaim, Z. Herz, and Y. Folman. 1991. The effect of GnRH administered to dairy cows during oestrus on plasma LH and conception in relation to the time of treatment and insemination. Anim. Reprod. Sci. 24:13-24.
Ryan, D. P., S. Snijders, T. Condon, M. Grealy, J. Sreenan, and K. J. O'Farrell. 1994. Endocrine and ovarian responses and pregnancy rates in dairy cows following the administration of gonadotrophin releasing hormone analog at the time of artificial insemination or at mid-cycle post insemination. Anim. Reprod. Sci. 34:179-191.

Saacke, R. G., J. C. Dalton, S. Nadir, R. L. Nebel, and J. H. Bame. 2000. Relationship of seminal traits and insemination time to fertilization rate and embryo quality. Anim. Reprod. Sci. 6061:663-677.

Schmitt, E. J., T. Diaz, C. M. Baros, R. L. de la Sota, M. Drost, E. W. Fredriksson, C. R. Staples, R. Thorner, and W. W. Thatcher. 1996. Differential response of the luteal phase and fertility in cattle following ovulation of the first-wave follicle with human chorionic gonadotrophin or an agonist of gonadotrophin-releasing hormone. J. Anim. Sci. 74:1074-1083.

Shaham-Albalancy, A., M. Nyska, M. Rosenberg, Y. Folman, and D. Wolfenson. 1997. Delayed effect of progesterone on endometrial morphology in dairy cows. Anim. Reprod. Sci. 48:159-174.

Shaham-Albalancy, A., Y. M. Rosenberg, Y. Folman, Y. Graber, R. Meidan, and D. Wolfenson. 2000. Two methods of inducing low plasma progesterone concentrations have different effects on dominant follicles in cows. J. Dairy Sci. 83:2771-2778.

Stevenson, J. S., E. C. Call, R. K. Scoby, and A. P. Phatak. 1990. Double insemination and gonadotrophin-releasing hormone treatment on repeat-breeding dairy cattle. J. Dairy Sci. 73:1766-1772.

Ullah, G., J. W. Fuquay, T. Keawkhong, B. L. Clark, D. E. Pogue, and E. J. Murphey. 1996. Effect of gonadotrophin-releasing hormone at estrus on subsequent luteal function and fertility in lactating Holsteins during heat stress. J. Dairy Sci. 79:1950-1953.

Wildman, E., G. M. Jones, P. E. Wagner, H. F. Troutt, Jr., and T. N. Lesch. 1982. A dairy cow body condition scoring system and its relationship to selected production characteristics. J. Dairy Sci. 65:495-501.

Wolfenson, D., H. Sonego, A. Bloch, A. Shaham-Albalancy, M. Kaim, Y. Folman, and R. Meidan. 2002. Seasonal differences in progesterone production by luteinized bovine thecal and granulosa cells. Domest. Anim. Endocrinol. 22:81-90.

Zelinski-Wooten, M. B., J. S. Hutchinson, I. Trinchard-Lugan, D. L. Hess, D. P. Wolf, and R. L. Stouffer. 1997. Initiation of periovulatory events in gonadotrophin-stimulated macaques with varying doses of recombinant human chorionic gonadotrophin. Hum. Reprod. 12:1877-1885. 